\title{
The Total Cost of Water-Related Disasters
}

\author{
Stefano Balbi, Carlo Giupponi, Roland Olschewski and Vahid Mojtahed*
}

\begin{abstract}
Water-related disasters have caused increasing losses in recent years. Efficient risk reduction policies require accurate assessment approaches, with careful consideration of costs, beyond material damages, which are commonly used in practice. Faced with possible risk reduction scenarios, limited financial resources require an improvement in the quality of cost estimation, thereby contributing to an efficient allocation of resources. This paper reviews the concept of total cost in the context of water-related disasters, elaborating on the typical direct/indirect and tangible/intangible cost categories. These categories are defined and explained, supported by a comprehensive assessment of economic valuation methods. Based on this information, practice relevant suggestions are made concerning the most appropriate methods for different cases in terms of scale, availability of data and of technical resources.
\end{abstract}

JEL classification: Q54

Keywords: natural disasters; flood risk, total cost; risk reduction measures; economic valuation

\section{Introduction}

A disaster is defined as the outcome of a hazard negatively impacting a combined human-natural system (OKUYAma and SAHIN, 2009; EEA, 2010). The magnitude of the disaster is directly related with the intensity of the hazard as well as with the exposure and the vulnerability of the system (CRICHTON, 1999). However, disasters can be assessed in many ways: number of deaths, number of building collapsed, kilometres of roads destroyed, money loss due to the disruption of economic activities,

* Stefano Balbi, Basque Centre for Climate Change (BC3), Alameda Urquijo 4, 4a , 48008 Bilbao Bizkaia, Spain, E-Mail: stefano.balbi@bc3research.org; CARLo GiUPPONI and VAHID Mojtahed, Department of Economics, Ca' Foscari University of Venice; Roland OLSCHEwSKI, Environmental and Resource Economics, Swiss Federal Research Institute WSL 
etc. Ideally all these elements should be comprised in a total cost assessment but practically most of the times only direct and tangible costs are considered to estimate the economic losses.

Economic losses due to natural disasters have been increasing in recent years (Downton and Pielke, 2005; WB-IEG, 2006; Bower et al., 2007; CRED, 2007; 2008; 2010; OKuYAma and SAHIN, 2009, UNISDR, 2009). When expressed as a portion of gross domestic product (GDP) estimated losses in developing regions, and particularly in the small island states, are generally higher than those in developed regions (IPCC, 2011). Although overall losses have been increasing worldwide over the past few decades, fatalities have decreased in developed countries, but increased in the developing countries (DORE and ETKIN, 2000). In addition, clime change is likely to exacerbate the natural disasters risk - "Impacts from recent climate-related extremes, such as heat waves, droughts, floods, cyclones and wildfires, reveal significant vulnerability and exposure of some ecosystems and many human systems to current climate variability (very high confidence)" (IPCC, 2014).

This article focuses on water-related hazards, and in particular on riverine floods, because they are the most costly hazard due to the frequency of events and to the characteristics of areas exposed. OKUYAMA and SAHIN (2009) show that in a global sample of 184 disasters over the previous 47 years, $25 \%$ of the total losses came from water-related disaster, while $40 \%$ of total losses were due to geophysical disasters such as earthquakes. However, several aspects considered in this study, can also be applied to the valuation of other typologies of hazard.

In Europe, riverine flood is the most dangerous typology of natural hazard in terms of economic losses (EEA, 2010). Between 2003 and 2009, 26 major events produced economic losses estimated around 17 billion EUR and 320 fatalities. The increased losses over the past decades are partly due to the increase of population and assets in the exposed areas (EEA, 2010). Indeed, integrated flood risk management has become a priority for the European Union that has established dedicated institutions and norms (e. g., EC, 2007; EFAS, 2010).

The magnitude of disasters' costs is co-determined by the ability of affected individuals and communities to absorb or cushion hazards (Rose, 2004b). However, until the $1990 \mathrm{~s}$, disaster management was primarily focused on the response of governments, communities, and international organizations in dealing with the consequences of disasters after they occurred. Since recently the focus has been significantly shifted to the role of knowledge and preparedness (UNISDR, 2004). The reason is twofold: (a) disaster occurrence is subject to intrinsic uncertainty and this will be exacerbated by climate change; and (b) the consequences of a disaster increasingly depend on the behaviour of the affected people and their ability to adapt. This is why the discourse of two of the main scientific communities working on natural disasters - "disaster risk reduction" (DRR) and "climate change adaptation" (CCA) - is progressively converging to the issues of vulnerability, adaptation, resilience and ultimately integrated risk management (GAIN et al., 2012). 
At a global level the United Nations International Strategy for Disaster Reduction is promoting the development of a process that shifts the focus from the protection against hazards to the management of hazardous risk, through the Hyogo Framework for Actions (UNISDR, 2005). The same process has been reinforced at the European level, where, in the case of floods, particular emphasis is put on non-structural risk reduction measures (GREEN et al., 2011). This process becomes even more relevant in view of the expected changes in future climate. Including climate change in the DRR framework improves the analytical framework because climate change is likely to bring hazards for which experience does not exist yet (UNISDR, 2004). In general, it could significantly affect the main features of hazardous events, in terms of magnitude, return period, geographical distribution and scale, etc. For instance, heavy precipitation is likely to increase at the northern and mid-latitudes in winter and an increase in the magnitude and/or frequency of rain-generated floods is anticipated in some catchments (TREnBERTH et al., 2007; BATEs et al., 2008; IPCC, 2011).

The rising costs of natural disasters make it a high priority to improve the quality and the reliability of the assessment approaches to comprehensively inform mitigation and risk management policies (Mysiak and MARKANDYA, 2009). Here, valuation clearly is a useful way to summarize the available information and economic assessment is usually the preferred approach, given that there is a tendency that political arguments have a higher impact when backed up by monetary figures (ECONOMIST, 2006). In the case of water-related disaster risk reduction, economic valuation is of great relevance for public policy in that it may help to determine the relative advantages of different possible measures. One may argue that most of the times a detailed estimation of material damages (direct and tangible costs) is sufficient to compare and justify the choice of alternative risk reduction measures, in particular when structural risk reduction measures (e.g., dikes, dams, embankments, etc.) are assessed. Whether this still holds when it comes to evaluating the benefits of non-structural measures and of preparedness is an open issue, since, for instance, the importance of intangible and indirect costs and benefits might substantially increase.

For example, by anticipating the hazard early warning system can reduce not only the amount of direct tangible costs - people can move transportable property outside of the exposed area - but they can also: (i) save human lives (direct intangible costs); (ii) change the behaviour of people avoiding long-lasting trauma (indirect intangibles costs); (iii) prevent post-disaster evacuation costs (indirect tangible costs).

In the following sections, we define the concept of total cost and build on the various categories of costs presenting specific examples for water-related disasters. Section 2.1 is dedicated to tangible costs, while Section 2.2 is focused on intangibles. Section 3 deals with valuation methodologies traditionally applied to the estimation of different costs and the research gaps in the quest for a comprehensive total cost assessment. In the last section, we highlighting several challenges for total cost estimations. 


\section{The total cost of water-related disasters}

The concept of total cost goes beyond traditional disaster assessment exercises (e. g., Albala-Bertrand, 1993; Wind et al., 1999), because it aims at determining the overall burden on a socio-ecosystem imposed by a disaster. In public economics it is approximated by the concept of social cost (COASE, 1960), which is symmetrical to that of total economic value (FREEMAN, 1979) used in environmental economics to estimate the benefits provided by natural resources.

The 'true' costs of disasters include costs (including benefit losses), which are difficult to identify and to quantify (Downton and Pielke, 2005). It comprises all direct, indirect, tangible and intangible costs. Direct costs are the costs due to the damages provoked by the hazard and which occur during the physical event; indirect costs are those induced by the hazard but occurring, in space or time, apart from the physical event. Tangible costs are those deriving from the economic impacts. Their estimation has been matter of a well-established body of research in the field of economics of natural disasters (NRC, 1999). Intangible costs are those values lost due to a disaster, which cannot, or are difficult and/or controversial to, be monetized, because they comprise non-market values (NRC, 1999). Intangibles mainly pertain to impacts on people and on the environment.

A comprehensive total cost assessment should also take into account the distributional effects of the disaster costs and of the policies to mitigate them (MYSIAK and MARKANDYA, 2009). A pre-requisite is the definition of the spatial and temporal boundaries of the assessment (Merz et al., 2010). As the WORLD BANK (2010) points out, economic impacts may not all be adverse, especially in areas outside the flood zone. For example, a flood might devastate a community. At the same time, nearby communities might experience economic benefits, since the flood might trigger business opportunities that cannot be exploited by the flood-affected companies. As reported in PIELKE (2000) the 1993 US Midwest floods impeded barges to navigate the river. Because of this lack of barge traffic, several trucking companies gained about 13 million US\$ in additional revenue due to the increased demand for road transportation.

VAN DER VEEN (2004) distinguishes among micro-, meso- and macro- spatial scales. This is, on the one hand, related to the spatial extent of the damage assessment. On the other hand, there is a methodological distinction of these approaches in their need for aggregation. The net effects of disasters will vary across the scales of aggregation: individuals, firms, communities, regions and nations (SCANLON, 1988; Cochrane, 2004).

Similar considerations hold concerning the temporal scale. Floods can cause longterm consequences, such as health effects, which are not captured if a too short time horizon of the damage assessment is chosen (MERz et al., 2010). In case of full monetization of such negative impacts the choice of the appropriate discount rate remains one of the most controversial issues in literature. 
A summary of the main costs of water-related disasters is presented in Figure 1. Given the definition of total cost, we framed the problem into four quadrants resulting from the categories of tangibility - characterized by market values - and directness characterized by contiguity in the space and time of the occurrence of the hazard. However, for the purpose of this paper, we emphasize the distinction between tangible and intangible costs (i. e. respectively the right and the left quadrants of Figure 1).

A full specification of a novel comprehensive methodological framework for assessing the total cost of water-related disasters has been presented in GiUPPONI et al. (2014) and demonstrated for the case of Dhaka megacity in GAIN et al. (2015).

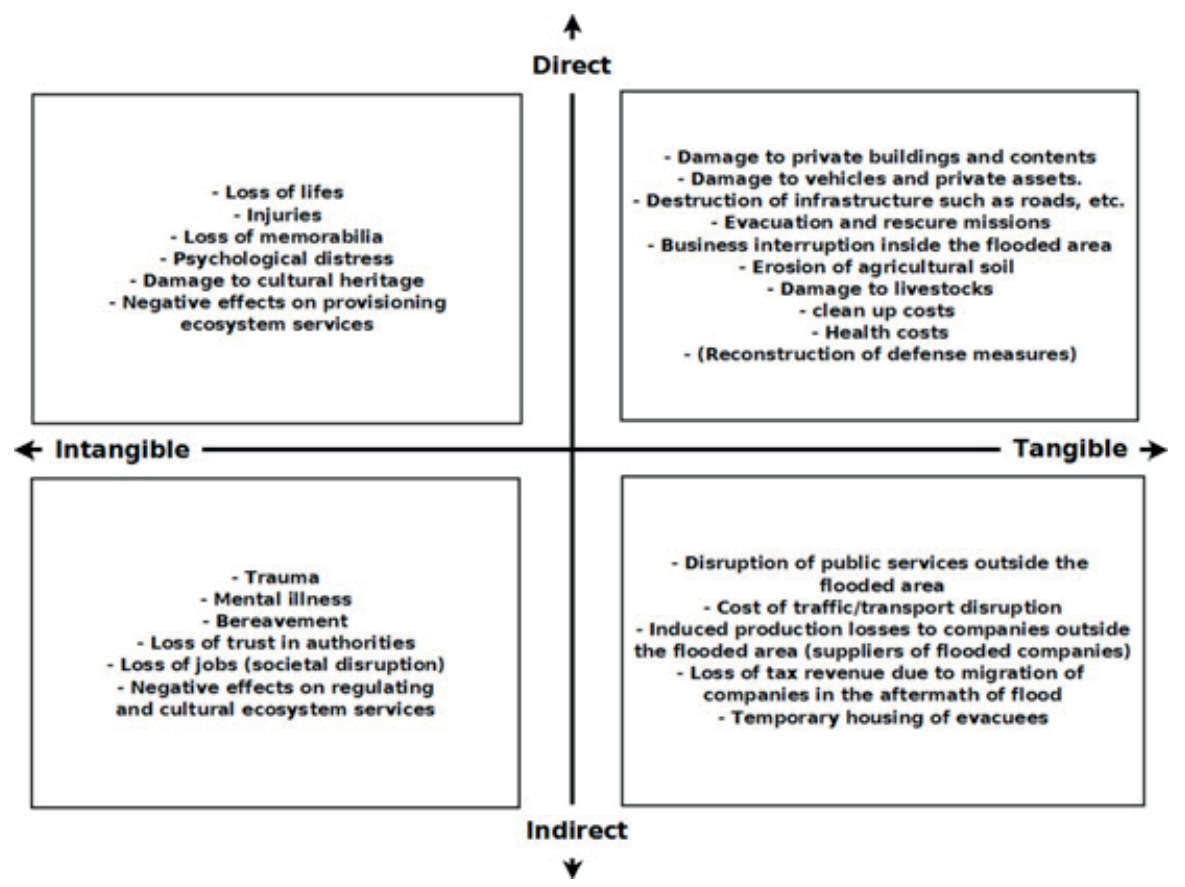

Figure 1: Total cost of water-related disaster (adapted from PENNING-RowselL et al., 2003; JonKMAn et al., 2008 and Merz et al., 2010).

\subsection{Tangible costs}

Tangible costs can be measured as direct losses of economic assets or stocks as well as the consequential indirect effects on the economic flows, such as GDP or consumption (ECLAC, 2003). There has to be a clear distinction between stocks and flows. The economic impacts can be identified as direct when stocks are impacted and indirect when flows are affected (Benson and Clay, 2003; Cavallo and Noy, 2010). 
In principle, each economic loss can be estimated either as a change in the stock or as a change in the flow (Rose, 2004a). The practice is to calculate whatever is easier to estimate. The stocks are counted as existing stocks (i. e. before the floods) directly impacted at a specific time (i. e. during the flood event). These stocks can also include the stocks for future production. In addition floods may induce a stop of production during the hazard event and afterwards, during the recovery phase. The losses of what could have been produced are preferably measured as losses to flows (GREEN et al., 2011). If both stock and flow values are used in the assessment, an essential rule is to monetize each individual component of a damage of any category either by stock values or by flow values (MESSNER et al., 2007). Including both for one component would lead to double counting.

However, double counting is frequent in practice (COCHRANE, 2004) also because the relationships between direct and indirect costs are not easy to capture (HeINZ CENTER, 2000; BTE, 2001). Following the "Source-Pathway-Receptor-Consequence" approach (GouldBY et al., 2005), which is adopted in flood damage assessments, it is common to distinguish between first, second, and third order effects depending on the contiguity of the consequence to the occurrence of the hazard. Direct costs would derive from first order consequences. Indirect costs would derive from higher order consequences.

First order consequences are located in the flooded area and they would potentially depend on the contact with water (GREEN et al., 2011). Direct costs of this type would include the value of damages to physical assets in the flooded area, but also the costs for emergency services, including public spending for evacuation and clean-up, and health costs. The costs for emergency services are easily measurable and often outweigh the remaining direct economic costs (Penning-Rowsell and WiLson, 2006).

Consequences of the second order may also unfold indirectly, affecting receptors near the flooded area and altering their activities (GrEen et al., 2011). This kind of consequences might depend on the network structure of the system rather than on the receptor's spatial proximity to the flood. For instance, if a minor road is flooded, it may induce indirect effects within a few kilometres. But if a railway is flooded, it may have consequence hundreds of kilometres around. If an international airport is flooded it will affect other parts of the world. Indirect costs of this type would include the costs due to the disruption of production and to traffic diversion.

The third order consequences are related to what is happening after the flood and during the recovery phase (GREEN et al., 2011). Indirect costs of this type would include: decline in investments, drop in national/regional income, opportunity costs of flood-related budget expenditure, increase in food imports, etc.

However, reconstruction can also lead to positive economic consequences: new investments may lead to a boom during the disaster recovery phase. Much depends on the availability of capital within the impacted area or from outside (OLSEN and PORTER, 2011). 


\section{Direct tangible costs}

After determining the costs of the emergency services, the second step of any waterrelated disaster assessment is to evaluate the cost of damages to the physical properties and economic assets. In general, and especially for large-scale disasters, it is not possible to assess the damage for each single object, because there is no information on the damages to every object and/or because such a detailed assessment would require a huge effort. Therefore, elements at risk are pooled into classes, and the damage assessment is performed for the different classes, whereas all elements within one class are treated in the same way (MERz et al., 2010).

A central idea in flood damage estimation is the concept of stage-damage functions. They relate damage for the respective element at risk to the characteristics of the inundation (i. e. the flood maps and the land-use maps reflecting the type and the density of objects at risk) (WIND et al., 1999; NRC, 2000). For physical assets such as buildings (contents and structure) two functions are commonly used: the relative (e. g., Kreibich et al., 2010) or the absolute function (e. g., Prattenthaler et al., 2010). The absolute function consists in establishing the damage function for a particular asset in monetary terms either in relation to the building or per unit area. The relative function provides the susceptibility expressed as a percentage of the total value of the assets.

Direct costing methodologies are quite well established in the literature, but there still seems to be a mismatch between the relevance of the damage assessment and the quality of the available models (e. g., the stage-damage functions) and datasets.

\section{Indirect tangible costs}

Indirect economic costs are those costs induced by direct damages and spread throughout the economic system (MERz et al., 2010) both in space and in time. The limitation of accessible primary data have led to attempts to measure indirect damages using economic models that have long been utilized for economic forecasting such as (1) regional econometric models, (2) input-output models (I/O), and (3) computable general equilibrium (CGE) models (Rose, 2004). Such kinds of models study the propagation of direct economic effects and lead to a total indirect cost estimate. As shown in OKUYAMA and SAHIN (2009), different kinds of disasters have different direct-toindirect costs multipliers ranging from 0.86 to 0.96 . The transferability of multipliers might be considered as a step towards a more accessible estimation exercise.

With regard to the temporal dimension, a major part of the analyses on indirect costs has focused on the effects of floods on income or gross domestic product (GDP) (GrEEN et al., 2011). Some of the main findings are that:

1. The effects of floods on growth might be significant in the short-term but insignificant in the medium and long term (AlBALA-BERTRAND, 1993);

2. There are positive effects after the disaster (i. e. recovery booming) if aid is provided (Merz et al., 2010). 
However, social costs of disaster are not accurately represented by the change in the GDP (EC, 2009). In this respect GDP is a misleading measure of well-being. For example, while flood risk reduction expenditures are counted in social cost assessment, at least part of them will, at the same time, be included positively in the calculation of GDP (EPA, 2008). Other indicators of welfare might be more appropriate For instance, Rodriguez-Oreggia et al. (2012) found that there is a significant impact from natural disasters on reducing the Human Development Index (HDI) and also on increasing poverty levels. In particular, in developing countries, given their relatively high level of vulnerability, floods may have significant negative consequences. An increase in indebtedness and trade imbalances can often be observed (Albala-Bertrand, 1993). Moreover, the frequency of floods is one of the main factors that impede sustained development in flood prone areas (UN, 2008). Other indirect costs might include the cost of inflation due to negative effects on the supply system (CAVAllo and Noy, 2010).

Concerning the spatial dimension, it has been argued that the aforementioned traditional economic system modelling techniques are inappropriate for simulating natural disasters and that those must be substantially revised in order to produce reliable estimates of indirect effects (MERz et al., 2010). Given the interconnectivity of economies and globalization, the causes and consequences of a disaster can be connected through complex networks. This may require computational algorithms for modelling supply shocks, post-event supply constraints and time phased reconstruction in disaggregated spatial settings (e. g., VAN DeR Veen and LogtMeIJer, 2005; YAMANo et al., 2007).

At the same time, other semi-quantitative approaches have explored the potential of stakeholders' inclusion and expert knowledge elicitation. PFURTSCHELLER and SCHWARZE (2010) developed a simplified vulnerability scorecard system to raise awareness of indirect effects in regional disaster management (MERZ et al., 2010).

\subsection{Intangible costs}

Intangible costs such as losses of human lives, cultural heritage, and ecosystem services have been largely neglected in the field of economics of natural disasters even though there is great body of work on the value of statistical life and on the evaluation of environmental goods (Krutilla and Fisher, 1985; Viscusi and Aldy, 2003).

These costs are more difficult to estimate for two reasons: (1) it might be difficult to identify them (e. g., what is the effect of a flood on an ecosystem?) (2) it might be difficult, controversial and inconvenient to monetize them. Apart from the ethical issues involved, for instance, in valuing human lives there exist a series of biases in the valuation of non-market goods, which depends on the methods applied. For example, some of these methods make use of hypothetical scenarios, which can undermine the credibility of results. Further, non-market valuation methods other than benefit transfer, might be highly resource and time consuming when there are multiple 
intangible costs to be taken into account in a single assessment, as it frequently happens at the meso-scale.

On the one hand, it could be accepted that intangible costs remain non-monetized, and thus are referred to as impacts. On the other, it is mandatory to identify and include them in any assessment that has the ambition of being realistic and comprehensive. In the following, we distinguish between impacts on people and impacts on the environment.

\section{Impacts on people}

Beside the economic losses, potential impacts on individuals are: mortality, injuries, and diseases (e.g., diarrhoeal, vector-borne) and infections, chemical pollution, nutrition and displaced population (FEW et al., 2004). Only a small part of these impacts is captured by direct health costs. Psychological or mental health impacts are also recognised and are related to various flood impacts such as the stress of the flood itself, the evacuation, the disruption to life and household and the loss of memorabilia and personal belongings (TAPSEL and PRIEST, 2009). Loss of cultural heritage is a further potential impact which can be associated to, but it is barely approximated by the damages to historic physical assets, as certain disaster might affect the folklore, traditions, language, and knowledge of the involved communities However, social benefits can also arise from the redistribution of assets and income in a community after a disastrous event (MCSwEENEY and CoOMS, 2011).

Indeed, in the public opinion, the tribute of lives is unanimously recognized as the most important impact of any disaster. In the last ten years, high losses of lives due to floods have mainly concerned developing countries, while in Europe the risk of dying directly by flood is relatively low. The main factors of risk are given by the high velocity and high depth associated with debris, which involve a loss of stability in the water and increase the risk of drowning. Time lag is also crucial as it constrains the potential time of warning and evacuation. Local circumstances (e. g., presence of shelters, type of buildings, time of the day, seasonality, warnings) play a strong role (GreEN et al., 2011).

Including mortality in a cost-benefit analysis implies the quantification of human lives in monetary terms. A comprehensive review of this issue is beyond the scope of this report, and thus, we refer to the literature on the value of statistical life, which is a concept widely applied for the evaluation of many health and safety initiatives (JONKmAN and VRIJling, 2008; Doucouliagos et al., 2011). Novel complexity-based approaches are now available which bypass the issue of monetization and include knowledge elicited from expert and stakeholders (e.g., BALBI et al., 2014; BALBI et al., forthcoming).

Current economic approaches limit the assessment of social capital to the level of the individual. Typically the number of flooded households is considered and eventually a specific factor is applied to adjust the number to the population size. However, negative effects can also result from floods such as social disorganization due to 
the loss of life, refugees, loss of trust in the authorities leading to the ruin of local economy or even to political change and instability (GreEN etal., 2011). For instance, repeated "false positive" flood alerts may undermine the trust in local authorities and impose an evitable load of stress to the population.

\section{Impacts on the environment}

Floods are natural phenomena that are related to characteristics of the specific catchment. The environment of a catchment is a mosaic of interdependent ecosystems, which develops around the prevailing water regime. Ecosystems and species can also be considered as hazards' receptors. Floods (and landslides) also have ecological effects, which might be favourable. Favourable effects include, for example, the benefits from the water and sediments that floods bring to wetland areas, thereby enhancing these locations as bird habitats. Floods thus help to maintain the natural character of these areas and the biotic diversity that they support (FLOODsITE, 2009). Unfavourable effects occur where floods invade areas with water intolerant ecosystems, or where floods lead to erosion or deposition of sediments to the detriment of the species normally based there, or where flood waters disperse pollutants that adversely affect floodplain habitats and/or their species (FLOODsiTe, 2009).

The ecosystem services framework is a useful lens to approach the study of flood impacts on the human societies (VILLA et al., 2014a) while maintaining a robust environmental perspective VILLA et al., 2014b). Floods may move good soil from one place to another, or bury cropland under sediments, significantly affecting its fertility in positive or negative terms. For plants, the seasonality is the most critical factor. Regular flooding of dry land during the growing season is undesirable but outside the growing season is relatively unimportant. Further, if a flood increases the availability of a nutrient in an area where naturally the soil is nutrient poor, then the result may be to change the species composition (GREEN et al., 2011). Thus, it is crucial to determine when and where a flood will have beneficial effects on the existing ecosystems and when it will have harmful effects. Many decisions involve environment-to-environment trade-offs such as the preservation of a dry land ecosystem or the enhancement of a wetland ecosystem (e. g., Leschine et al., 1997). This might imply the evaluation and prioritization of the ecosystem services (ME, 2003). Primary sector activities such as agriculture, forestry, fisheries and hunting depend on a wide range of provisioning and regulating services that together shape the natural capital on which these sectors depend (CHIABAI et al., 2009). The potential decrease in the quality of soil and the loss of soil structure are definitely to be considered as intangible environmental impacts. Considering the environmental implications of catchment and floodplain management options for water-related disaster risk reduction may also be relevant. These could include changes in run-off and flood characteristics in each compartment of the catchment. 


\section{Valuation methodologies}

In the first part of this section, we briefly review the main cost estimation methodologies, which have been applied to water-related disasters. The methods reported here, and summarized in Table 1, could be divided into three main clusters of valuation techniques: (1) market-based (MB), (2) non-market-based (NMB), and (3) traditional and integrated economic system modelling (T\&IESM). In Table 1 the capacity of each method in addressing the different categories of costs is considered. Additionally, the appropriateness of each method with regard to scale, data and resources availability is analysed. One reference for each method and a typical example are provided.

\subsection{Market-based approaches}

This set of methods uses market-based indicators in cases, where the environmental goods and services can be associated with competitive markets (EFTEC, 2010).

The market price method is mainly used to estimate the economic value of any product or service that is bought and sold in commercial markets. It can be used to value changes in the quantity or quality of a good or service. The estimation starts with assessing the quantity people purchase at different prices (demand curve) and the quantity supplied at different prices (supply curve). In the case of quality change, one observes a change in the market demand function for a good or service (consumer's surplus) and a change in benefits or losses of producers (producers' surplus). The sum of surpluses represents the total net economic benefit of a good or service in a market (LOGAR and VAN DEN BERGH, 2012).

A production function approach (also known as dose-response) estimates a function that specifies the output of a company, an industry or the whole economy based on the combination of inputs (LOGAR and VAN DEN BERGH, 2012). Econometric analysis is used to relate output to inputs. The same approach can be used to derive inverse demand functions based on the observation of consumers' behaviour. An important caveat of this method is that production functions are often not known as precisely as needed.

The cost of restoring the environment to its original state is estimated by applying the replacement cost method (BROUWER, 2006). The replacement or repair cost approach assumes that the costs of replacing or repairing an ecosystem good or service represents a reasonable estimate of its value. On the one hand this method is often seen as a lower bound to the real value of the good or service (LOGAR and VAN DEN BERGH, 2012). On the other hand this method is often used for very detailed analysis at the micro-scale, where the costs can easily be overestimated if the depreciated values of the elements that need to be replaced are not taken into account. 


\begin{tabular}{|c|c|c|c|c|c|c|c|c|c|}
\hline 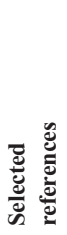 & 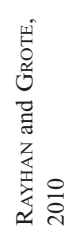 & 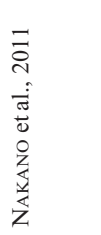 & 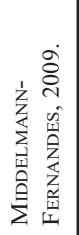 & 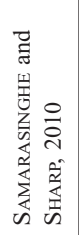 & 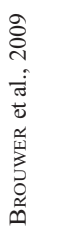 & 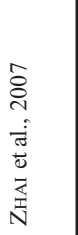 & 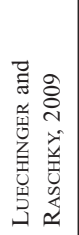 & 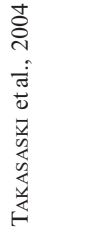 & 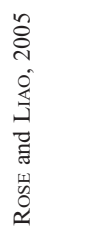 \\
\hline 胥 & $\frac{w}{\frac{n}{0}}$ & 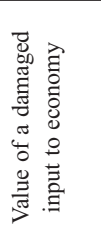 & 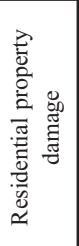 & 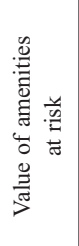 & 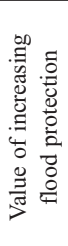 & 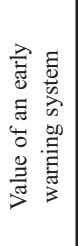 & 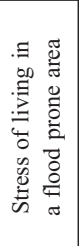 & 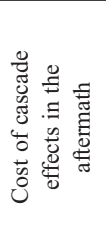 & 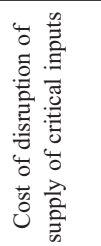 \\
\hline 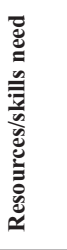 & 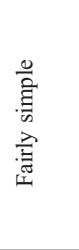 & 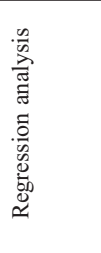 & 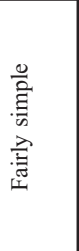 & 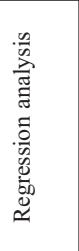 & 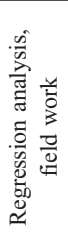 & 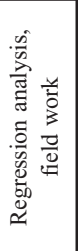 & 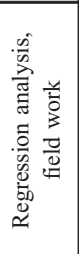 & 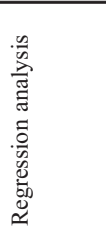 & 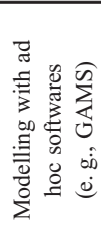 \\
\hline 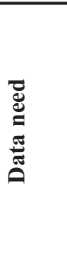 & 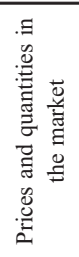 & 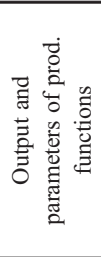 & 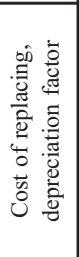 & 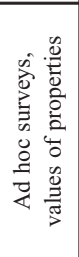 & 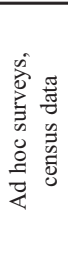 & 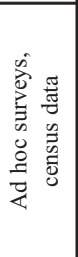 & 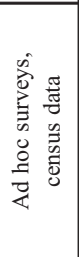 & 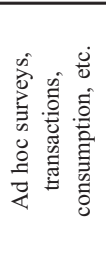 & 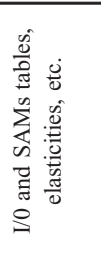 \\
\hline 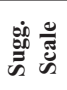 & $\sum_{\substack{0 \\
\sum}}^{\infty}$ & $\stackrel{8}{\stackrel{0}{2}}$ & $\sum_{\substack{\infty \\
\Sigma}}^{\infty}$ & $\stackrel{8}{\stackrel{0}{2}}$ & : & : & $\stackrel{8}{\stackrel{0}{2}}$ & $\sum_{\substack{\mathscr{m} \\
\Sigma}}$ & $\begin{array}{l}\text { : } \\
\text { ¿ूँ }\end{array}$ \\
\hline$\dot{\Xi} \dot{\Xi}$ & & & & $x$ & $x$ & $x$ & $x$ & & \\
\hline$\dot{\vec{\theta}} \dot{\Xi}$ & & & $x$ & $x$ & $x$ & $x$ & $x$ & & \\
\hline 灾 & $x$ & $x$ & & & & & & $x$ & $x$ \\
\hline 芦 & $x$ & $x$ & $x$ & & & & & $x$ & $x$ \\
\hline 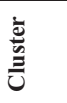 & $\stackrel{m}{\Sigma}$ & $\stackrel{n}{\Sigma}$ & $\stackrel{\oplus}{\Sigma}$ & $\sum_{\Sigma}^{\infty}$ & $\sum_{\Sigma}^{m}$ & $\sum_{z}^{m}$ & $\sum_{z}^{\infty}$ & 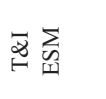 & 总础 \\
\hline 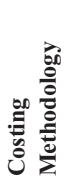 & 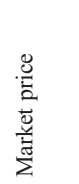 & 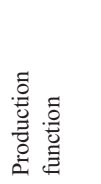 & 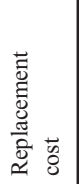 & 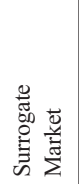 & 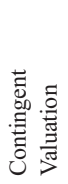 & 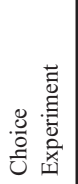 & 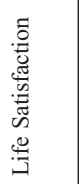 & 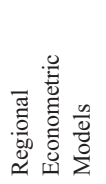 & 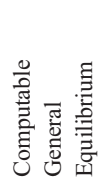 \\
\hline
\end{tabular}




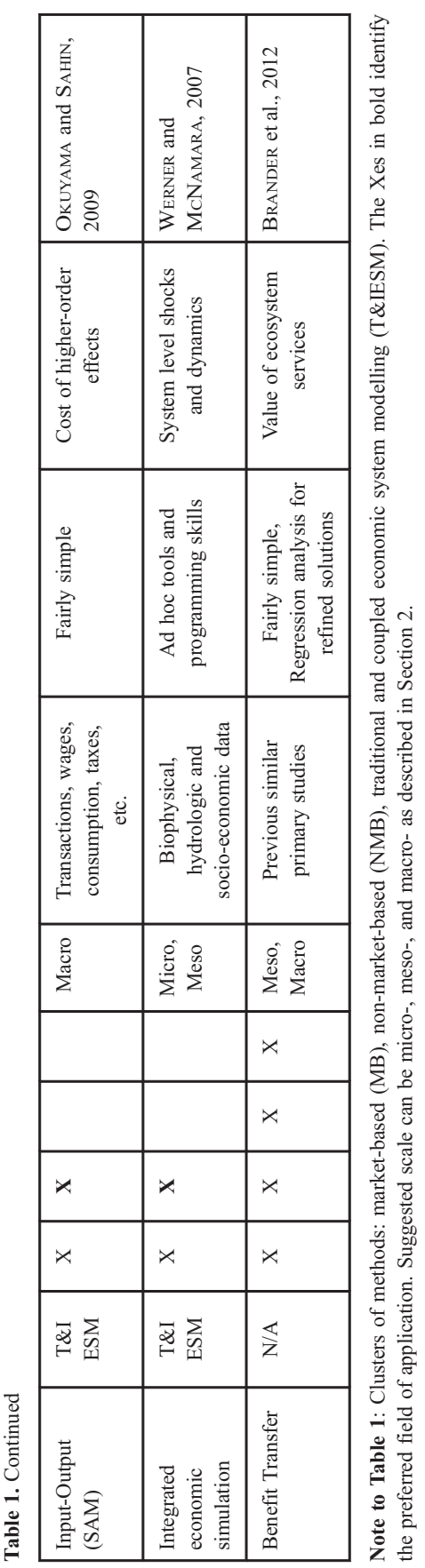


The appropriateness of these methods is limited to cases, where there are markets or where shadow prices can be estimated, thus they may not be used to estimate nonuse values ${ }^{1}$.

\subsection{Non-market based approaches}

Although many environmental or cultural goods and services are not traded in the market, their characteristics affect demand of other goods and services, which are traded in the market (EFTEC, 2010). These goods are generally a subclass of public goods, which are defined by non-excludability and non-rivalry. For determining their damage potential, the public value has to be estimated on the basis of people's preferences. The non-market value of environmental or cultural goods can be decomposed into several sub-categories. We need to distinguish between 'use value' and 'non-use value' of these goods (ArRow et al., 1993). The total use value generated by the site is the sum of the all individual visitors' willingness to pay (WTP) for using the commodity. Narrowing the value of cultural and environmental goods to the use-value often leads to a bias for globally important sites as their direct users often comprise more than local residents.

The non-use value estimation might be motivated by the aim to cover the fact that a site is available for others to visit (altruistic value), or the site is preserved for future generations (bequest value), or the current non-visitor might decide to become a visitor in the future (option value), or simply the site is preserved even if no one ever actually visits it (existence value) (Throsby, 2003; 2007; IACOB et al., 2012). Researchers are advised to embed questions regarding bequest, existence and option values in their questionnaires to avoid under-estimation of economic value of environmental or cultural goods. Considerations of all the above mentioned motives expand the extent of the market, and include a larger number of potential national or international contributors.

The three following methods rely on this assumption and thus are known as surrogate market or revealed preference methods.

i) The avertive behaviour and defensive expenditures technique is focused on averting inputs as substitutes for changes in environmental characteristics (EPA, 2008).

ii) Travel cost method originally proposed by HoteLLING (1947) uses questionnaires to elicit the transport costs and the time value for implicitly assessing the price of an environmental service (BROUwER, 2006; EPA, 2008). This method can be further developed along two lines:

a) The zonal travel cost method due to CLAwson and Knetsch (2013) splits the visitors into groups based on distance of visitors given their point of origin from

1 Non-use value (also known as passive value) refers to the value of a good of commodity for those who do not directly consume the good but benefit from its existence. 
the recreational site. In the next step, the demand curve is based on the reaction function derived from the average travel cost and the number of visits from each zone. The area under the demand curve represents the consumer surplus, which approximates monetary value of visiting the site.

b) The individual travel cost method, which attempts to estimate the demand of the recreational good for each individual at a given site. This method is more appropriate, when the travel costs of visitors from the same zone might vary from person to person. Once the individual demand functions are aggregated, an aggregate demand function is derived. This method has several practical problems as shown in BEDATE et al. (2004).

For water-related disasters the travel cost method might be well suited to estimate the costs of traffic disruption (GREEN et al., 2011).

iii) The hedonic price method is applicable to environmental and cultural attributes likely to be capitalized into the price of housing and/or land (BROUWER, 2006). This method employs the differences in the prices of marketed goods to derive the value of environmental and cultural characteristics (EPA, 2008). Thus, market distortions can bias the obtained prices. RUIJGROK (2006) employing hedonic price method studies the price of 591 residential houses near to a historical zone in the Netherlands. He estimated a benefit of 21.6 Million EUR for the cultural heritage conservation.

Both travel cost and hedonic price methods are based upon revealed preferences and make use of multivariate regression technique. Alternatively, methods related to stated preferences are based on interviewing the final beneficiaries and derive their surplus value changes.

The following three methods are applied to estimate economic values where there are no market-based prices and consumer behaviour data (EFTEC, 2010).

i) The contingent valuation method $(\mathrm{CV})$ is used to evaluate non-market resources with a structured survey. CV uses questionnaires, which are functional to collect respondents' WTP and/or willingness to accept compensation (WTA) with respect to an environmental damage (GREEN et al., 2011). The economic values estimated via CV are contingent upon a hypothetical market or governmental plan. Thus, the data generated this way is based on hypothetical scenarios. Some of the main problems with this method are: (a) the strategic bias, when respondents intentionally give responses that do not reflect their "true" values; (b) the costs of the studies; (c) time constraints (the practical implementation of the CV could require six months to a year); (d) the self-reported WTP is significantly higher than actual WTP (SEIP and STRAND, 1992); (e) difficulties with determining the scope of the market; (f) inconsistency with the assumption of rational choice (KAHNEMAN and KNETCH, 1992); (g) budget constraints is often not reminded in the studies. Despite the drawbacks, it is considered the only method for estimating non-use values. For example, RUIJGROK (2006) using CV method estimated the benefits of recreation and bequests to be 1.22 EUR (per visit) and 11.88 EUR (per year per household) respectively based on 380 interviews that he conducted. Out of 380 respondents, $85.2 \%$ were willing to pay for preserva- 
tion of cultural heritage in their area. Furthermore, considering the 2.8 million direct users living in the three provinces nearby, the total bequest value was estimated near EUR 34 million per year.

ii) In choice experiments the individuals have to compare different alternatives described by an array of attributes, including a cost or price attribute (OLSCHEWSKI ETAL., 2012). The set of possible choices has an important impact on the results and may be difficult to handle for the respondents (MCFADDEN et al., 2005). As for the $\mathrm{CV}$, it is required to have a substantial knowledge of econometric analysis and statistics (BROUwER, 2006).

iii) Life satisfaction analysis is a typical multidisciplinary approach. This method makes use of surveys to ask people to assess their current level of happiness. Economic values are determined based on the respondents' answers and additional socioeconomic indicators such as: income level data and environmental conditions. This data is processed with econometric modelling techniques (e. g., regression analysis) (Clark and Oswald, 2002; Logar and van Den Bergh, 2012).

\subsection{Traditional and integrated economic system modelling}

Different types of models of the economic system are also employed to explore in particular the indirect costs of a disaster. Most well established methods tend to model abstract economic systems disconnected from the surrounding environmental systems. Other tend to loosely couple the different systems, and few aim at a full integration.

Optimization models are used to provide mathematical solutions to problems that entail maximization or minimization of an economic objective subject to specific constraints. Given the problem's optimal solution, the model reveals the inputs' economic value. In particular, linear programming can provide guidance regarding optimal (maximum value added) allocation of scarce post-event production capacity (CoCHRANE, 2004). Linear programming minimizes or maximizes an objective function by choosing a set of decision variables, under a set of linear constraints, like available technologies, productive capacities, fuel supplies and regulations (EPA, 2008).

Regional econometric models represent historical trading patterns and are useful only in case they reflect balanced and undistorted economies. Regional econometric models are based on panel data. These models include estimates on employment, wages, incomes, population, and prices of a specific region, and use equations that represent the interregional trade of the industry and the in-and-out migration flows. They are capable to explain how an economic change in one region spills over to other regions and creates a feedback effect in the original one (GREENBERG et al., 2007).

Computable general equilibrium (CGE) analysis examines the economy-wide impacts of a change in a policy, technology, exports, or other exogenous factors (LoGAR and VAN DEN BERGH, 2012). CGE addresses the problem of uneven supply shocks and simulates the price system in a market economy. CGE models are useful to reproduce the economic losses as a percentage of GDP (SAHIN, 2011). However, the main 
purpose is to analyze the interactions between many and different economic agents each of which is represented by an equation (GREENBERG et al., 2007; LoGAR and VAN DEN BERGH, 2012; SAHIN, 2011). This method is suitable for macroeconomic assessments and for long-run equilibrium analysis, but it is based on several assumptions, such as (1) optimizing behaviour of consumer and producers (which is questionable under disaster situations), (2) market-clearing or (3) competitiveness of product and factor markets. Several attempts have been made to couple CGE models with environmental models (e.g., climatic and hydraulic), however available CGE models still prove to be primitive tools that are ill-suited when capturing most environmental concerns (SCRIECIU, 2007).

Input-Output (I/O) models are built around a matrix that registers the use of factors of production (e. g., labor, capital, land) and other inputs in the production of specific goods. Thus it is possible to reflect the economic interdependencies within a macroregional economy (OKUYAMA and SAHIN, 2009), using a table that describes the interrelated flows of goods and factors of production over the course of a year. $\mathrm{I} / \mathrm{O}$ econometric models integrate the conventional I/O models with econometric macroeconomic models. These models are often used to estimate the policies and regulations regional impacts, and also long-run impacts (EPA 2008). The I/O method can substitute CGE and it's easier to apply, although it is even more restrictive in terms of assumptions about production factors and technological change (LOGAR and VAN DEN BERGH, 2012). Social accounting matrixes (SAMs) are particular I/O matrixes that compile all the monetary flows among agents and sectors from a particular economy. They are widely used in the international development community to examine the indirect effects across different socio-economic agents, activities and factors at a coarse resolution (OKUYAMA and SAHIN, 2009). However, these models assume fixed technology and productivity, making future transactions patterns identical to the current one (GREENBERG ETAL., 2007). Further, they are incapable of capturing the price changes effects due to a disaster. The linearity and the rigid structure may lead to overestimation of impacts (GREENBERG et al., 2007; Rose, 2004; EPA 2008).

Integrated economic simulation tends to fully integrate the modelling of coupled human and environmental systems taking into account the socio-economic dimension amongst the others. Biophysical-agro-economic models provide comprehensive insights into the feedback effects between human activities and natural resources. When applied to the agricultural system they produce biophysical estimates of crop responses to climate events, with the use of spatially explicit models on different geographical scale (e. g., BALBI et al., 2010; BALBI et al., 2013; BALBI et al., 2015). The obtained estimates are incorporated into socio-economic models to predict farmers' decisions (or decisions of other human agents, e. g., households), and then to aggregate these decisions at the market level to forecast changes in supply prices (LoGAR and VAN DEN BERGH, 2012). Coupled water-related-economic models constitute a well-established typology of these models. They have three components: (1) a waterrelated component, (2) an economic optimization model, and (3) an institutional factor (LOGAR and VAN DEN BERGH, 2012). These models are mainly used to analyse 
the impacts of water allocation and they are used by different sectors under alternative policy scenarios. The currently developed integrated economic simulation models are more oriented towards the possibilities offered by the advances in computer science and yet partially implemented in the field of computational economics, social simulation, and ecology (BALBI and GiUPPONI, 2010). This approach studies the human society, the economy and the surrounding environment as interrelated complex systems that can be represented in their disaggregated form by employing a set of methodologies, most notably agent-based modelling, network theory and Bayesian networks, geographical information systems, etc. However, there still exist some scepticism about formalization, testing and use of this generative type of knowledge.

Finally, benefit transfer is a method that actually does not belong to any of the clusters presented and it is added here as it's often the simplest and most cost-effective way when other pertinent primary studies are available. Benefit transfer is the transfer of economic values estimated in an original study to a spatially and temporally different one. This practice is accepted when the characteristics and the context of the original study are similar to the new one. It is less time and resource consuming than the previous methods and therefore widely applied in meso- and macro- contexts where multiple single estimations would otherwise have been applied. Note that more refined benefit transfers exist (i. e. function transfer, meta-analysis) rather than the mere application of previously estimated values.

\section{Conclusion and perspectives}

The concept of total cost is highly ambitious, because it aims at determining the total burden imposed by a disaster to a coupled human-environmental system, including costs (including benefit losses), which are difficult to identify and quantify. It comprises all direct, indirect, tangible, and intangible costs. While most of the disaster cost assessments focus on one of the quadrants of the total cost matrix (see Figure 1), very few studies are available in the literature which tackle the entire complexity that underpins this framework (GIUPPONI et al., 2013).

Intangible costs, in particular, have been widely neglected in the field of economic valuation of natural disasters.

General motivations that are usually brought forward by experts to explain this gap are:

(1) including these costs in an assessment is considered to be too challenging and resource consuming;

(2) a one dimensional result might not be considered acceptable by a decision maker, especially when ethical implications are strong (e.g., aggregation of asset values and human life values);

(3) the estimation of total costs could lead to the justification of any risk reduction investment in a cost-benefit analysis context. 
However, all these motivations do not seem to capture the real essence of the problem. In fact, firstly, resource-consuming challenges are usually those boosting innovative solutions in the research arena. Secondly, ethical implications in valuing nonmarket goods have never constrained the research in environmental and health economics. Further, figures coming from different typology of costs could also remain non-aggregated in the total cost matrix framework. Finally, the third point may not hold when it comes to the valuation of trade-offs among non-structural measures of risk reduction.

The real justification of this gap might become clearer when adding the notion of scale to the discourse (i. e. micro-, meso-, and macro-, according to the biophysical, administrative and temporal boundaries imposed to the system under analysis). Table 1 has made explicit the fact that it is extremely difficult to find methods that can efficiently cover all cost categories for all scales.

For instance, most of the methods (mainly NMB) that are widely implemented for the estimation of intangible costs are more appropriate for the micro-scale. However, micro-scale studies are often not suitable for capturing indirect effects, both in spatial and temporal terms.

With regard to the meso-scale, which is often of major interest for the water basin authorities, it becomes difficult to apply the same NMB methods to estimate intangible costs because this would require a lot of resources (e. g., these methods require time and money and cannot be generalized to diverse intangible assets). In those cases, it is cost-effective to refer to benefit transfer, at the expense of precision and methodological challenges. At the macro-scale the application of benefit-transfer is theoretically feasible, but often the analyses are carried out at a highly aggregated level, which makes it difficult to determine appropriate values.

Total cost assessments should always be tailored to the case study according to its boundaries and the available data. Consequently, a priori, no single methodology should be excluded. If the aim is the full monetization of impacts for ease of comparison, one might derive that the role of benefit transfer emerges as strategic. However, full monetization is not necessarily the final aim of a total cost assessment, mainly because reducing the complexity of natural disasters to a one dimensional indicator might turn to a double edge sword for decision makers. On the contrary the total cost is a powerful framework to approach the entire complexity of natural disasters and their intertwining with coupled human-natural systems. Further research and discussion concerning the chances and limits of benefit transfer is needed, in particular, looking at how the existent scientific knowledge is sufficient and/or properly organized to facilitate the interoperability of different modelling approaches. 


\section{References}

Ahern, M., R. S. Kovats, P., Wilkinson, R. Few and F. Matthies (2005). Global health impacts of floods: epidemiologic evidence, Epidemiologic Reviews 27(1): 36-46.

Albala-Bertrand, J. M. (1993). Political economy of large natural disasters with special reference to developing countries. Oxford: Clarendon Press.

Arrow, K., R. Solow, P. R. Portney, E. E. Leamer, R. Radner and H. Schuman (1993). Report of the NOAA panel on contingent valuation. Available from: http://www. darrp.noaa.gov/library/pdf/cvblue.pdf [Accessed 27, July, 2015].

BALBI, S. and C. Giupponi, (2010). Agent-based modelling of socio-ecosystems: a methodology for the analysis of adaptation to climate change, International Journal of Agent Technologies and Systems 2(4): 17-38.

Balbi, S., P. Perez and C. Giupponi, (2010). A spatial agent-based model to explore scenarios of adaptation to climate change in an alpine tourism destination, University Ca' Foscari of Venice Dept. of Economics Research Paper Series 05(10).

Balbi, S., S. Bhandari, A. K. Gain and C. Giupponi (2013). Multi-agent agro-economic simulation of irrigation water demand with climate services for climate change adaptation, Italian Journal of Agronomy 8(3): 23.

Balbi, S., F. Villa, V. Mojtahed and C. Giupponi (2014). Estimating the Benefits of Early Warning Systems in Reducing Urban Flood Risk to People: A Spatially Explicit Bayesian Model. In 2014 Proceedings of the 7th Intl. Congress on Env. Modelling and Software, San Diego, CA, USA.

BALBI, S., et al. (2015). Modeling trade-offs among ecosystem services in agricultural production systems, Environmental Modelling \& Software.

Balbi, S., F. Villa, V. Mojtahed, K. T. Hegetschweiler and C. Giupponi (forthcoming). A Bayesian network model to assess the benefits of early warning systems in reducing urban flood risk to people. Submitted to Ecological Economics.

Bedate, A., L. C. Herrero and J. Á. Sanz (2004). Economic valuation of the cultural heritage: application to four case studies in Spain, Journal of cultural heritage 5(1): 101111 .

Bates, B. C., et al., (2008). Climate change and water. Technical Paper of the Intergovernmental Panel on Climate Change. Geneva: IPCC Secretariat.

Benson, C. and E. Clay (2003). Disasters, vulnerability, and global economy, in A. Kreimer, M. Arnold and A. Carlin (eds.) Building safer cities: the future of disaster risk, World Bank, Washington DC, 3-32.

Bouwer, L. M., et al., (2007). Confronting disaster losses, Science 318, 753.

BRANDER, L.M., et al., (2012). Using meta-analysis and GIS for value transfer and scaling up: Valuing climate change induced losses of European wetlands, Environmental and Resource Economics 1-19.

Brouwer, R., (2006). Practical working definition environmental and resource costs and benefits AquaMoney Project, Deliverable D12. Amsterdam: IVM, Free University. Available from: http://www.ivm.vu.nl/en/projects/Projects/economics/aquamoney/project-deliverables/index.asp [Accessed 27, July, 2015].

Brouwer, R., S. Akter, L. Brander and E. Haque (2009). Economic valuation of flood risk exposure and reduction in a severely flood prone developing country, Environment and Development Economics 14(3): 397.

BTE (2001). Economic costs of natural disasters in Australia. Canberra: Department of Infrastructure and Transport, Bureau of Transport Economics. 
Cavallo, E. and I. Noy (2010). The economics of natural disasters: a survey, IDB Working Paper Series 124: 1-49.

Chiabai, A., C. Travisi, H. Ding, A. Markandya, and P. A Nunes (2009). Economic valuation of forest ecosystem services: methodology and monetary estimates, FEEM Working Papers 272: 1-34.

Clark, A. E. and A. J. Oswald (2002). A simple statistical method for measuring how life events affect happiness, International Journal of Epidemiology 31(6): 1139-1144.

Clawson, M. and J. L. Knetsch (2013). Economics of outdoor recreation (Vol. 3), Routledge.

CoAse, R. H. (1960). The problem of social cost, Journal of Law and Economics 3: 1-44.

Cochrane, H. (2004). Economic loss: myth and measurement, Disaster Prevention and Management 13(4), 290-296.

CRED (2007). Annual disaster statistical review: numbers and trends 2006. Brussels: CRED.

CRED (2008). Annual disaster statistical review: the numbers and trends 2007. Brussels: CRED.

CRED (2010). Annual disaster statistical review 2009: the numbers and trends. Brussels: CRED.

Crichton, D. (1999). The risk triangle, in J. Ingleton (ed.) Natural disaster management, Tudor Rose, London, 102-103.

Dore, M. and D. ETKIN (2000). The importance of measuring the social costs of natural disasters at a time of climate change, Australian Journal of Emergency Management 15(3): 46-51.

Doucouliagos, H., T. D. Stanley and M. Giles (2011). Are estimates of the value of a statistical life exaggerated?, Deakin University Economics Series 2: 1-28.

Downton, M. W. and R. A. Pielke, JR. (2005). How accurate are disaster loss data? The case of U.S. flood damage, Natural Hazards 35: 211-228.

EC (2007). Directive 2007/60/EC of the European Parliament and of the Council of 23 October 2007 on the assessment and management of flood risks.

EC (2009). COM (2009) 433 final. GDP and beyond: measuring progress in a changing world.

ECLAC (2003). Handbook for estimating the socio-economic and environmental effects of disasters, UN ECLAC-World Bank, Washington DC.

Economist (2006). Big questions and big numbers - economic models (we cannot live without big and ambitious economic models. But neither can we entirely trust them). The Economist, 15 July, 66-68.

EEA (2010). Mapping the impacts of natural hazards and technological accidents in Europe, an overview of the last decade. Publications Office of the European Union, Luxembourg.

EFAS (2010). European Flood Alert System [website]. EFAS-IS Portal. Available from: https://www.efas.eu/ [Accessed 27, July, 2015].

Eftec (2010). Scoping study on the economic (or non-market) valuation issues and the implementation of the water framework directive. Economics for the Environment Consultancy Ltd, London.

Few, R., M. Ahern, F. Matthies and S. Kovats (2004). Floods, health and climate change: a strategic review, Tyndall Centre for Climate Change Research Working Paper 63: $1-138$.

FLOODsite, (2009). Flood risk assessment and flood risk management. An introduction and guidance based on experiences and findings of FLOODsite (an EU-funded integrated project). FLOODsite Project, Report T29-09-01 Ed. 2. Available from: http:// www.floodsite.net/html/publications2.asp?documentType $=1$ [Accessed 27, July, 2015]. 
Freeman, A. M. (1979). The benefits of environmental improvement: theory and practice. The Johns Hopkins University Press, Baltimore.

Gain A. K., C. Giupponi, and F. G. Renaud (2012). Climate change adaptation and vulnerability assessment of water resources systems in developing countries: a generalized framework and a feasibility study in Bangladesh, Water 4: 345-36.

Gain A. K., V. Mojtahed, C. Biscaro, S. Balbi and C. Giupponi (2015). An integrated approach of flood risk assessment in the eastern part of Dhaka City, Natural Hazards.

Giupponi, C., V. Mojtahed, A. K. Gain and S. Balbi (2013). Integrated Assessment of Natural Hazards and Climate Change Adaptation: I-The KULTURisk Methodological Framework, University Ca' Foscari of Venice Dept. of Economics Research Paper Series 6(13).

Giupponi, C., V. Mojtahed, A. K. Gain, C. Biscaro and S. Balbi (2014) Integrated risk assessment of water-related disasters, in P. PARON and G. Di BALdassare (eds.) Hydro-meteorological hazards, risks and disasters. Elsevier, Amsterdam, 163-200.

Gouldby, B., et al. (2005). Language of risk-project definitions. FLOODsite Project, Report T32-04-01 Ed.1. Available from: http://www.floodsite.net/html/publications2.asp? document Type $=1$ [Accessed 27, July, 2015].

Green, C., C. Viavattene and P. Thompson (2011). Guidance for assessing flood losses. Middlesex University. ConHaz Project, Deliverable 6.1. Available from: http://conhaz. org/project/cost-assessment-work-packages/wp1-8-final-reports [Accessed 27, July, 2015].

Greenberg, M.R., M. Lahrand and N. Mantell (2007). Understanding the economic costs and benefits of catastrophes and their aftermath: a review and suggestions for the U.S. federal government, Risk Analysis 27(1): 83-96.

Heinz CENTER (2000). The hidden costs of coastal hazards: implications for risk assessment and mitigation. Island Press, Washington DC.

Hotelling, H. (1947). Letter to the national park service. An Economic Study of the Monetary Evaluation of Recreation in the National Parks (US Department of the Interior, National Park Service and Recreational Planning Division, 1949).

Iacob, M., F. Alexandru, M. Kagitci, G. C. Creţan, and F. Iorgulescu (2012). Cultural heritage evaluation: a reappraisal of some critical concepts involved, Theoretical and Applied Economics 12(12): 61.

IPCC (2011) Summary for Policymakers, in FIELD, C. B., et al. (eds.) Intergovernmental Panel on Climate Change Special Report on Managing the Risks of Extreme Events and Disasters to Advance Climate Change Adaptation. Cambridge University Press, Cambridge.

IPCC (2014) Summary for Policymakers, PACHauri, R. K., et al. (eds.) Climate Change 2014: Synthesis Report. Contribution of Working Groups I, II and III to the Fifth Assessment Report of the Intergovernmental Panel on Climate Change.

Jonkman S. N. and J. K. VRiJling (2008). Loss of life due to floods, Journal of Flood Risk Management: 1(1), 43-56.

Jonkman, S., M. Bockarjova, M. Kok and P. Bernardini (2008). Integrated hydrodynamic and economic modelling of flood damage in the Netherlands. Ecological Economics 66(1): 77-90.

KAhNemAn, D. and J. L. KNETSCH (1992). Valuing public goods: the purchase of moral satisfaction. Journal of environmental economics and management 22(1): 57-70. 
Kreibich, H., I. Seifert, B. Merz and A. H. Thieken (2010). Development of FLEMOcs - a new model for the estimation of flood losses in the commercial sector, Hydrological Sciences Journal 55(8): 1302-1314.

Krutilla J. V. and A. C. Fisher 1985. The economics of natural environments: studies in the valuation of commodity and amenity resources. The Johns Hopkins University Press, Washington DC.

Leschine, T. M., K. Wellman and T. H. Green (1997). The economic value of wetlands - wetlands' role in flood protection in western. Washington State Department of Ecology. Available from: http://www.ecy.wa.gov/pubs/97100.pdf. [Accessed 27, July, 2015].

Logar, I., and J. C. van den Bergh, 2012. Methods to Assess Costs of Drought Damages and Policies for Drought Mitigation and Adaptation: Review and Recommendations. Water Resources Management 27(6): 1707-1720.

Luechinger, S., and P. A. RaschKy (2009). Valuing flood disasters using the life satisfaction approach, Journal of Public Economics 93(3-4): 620-633.

Mc Fadden, D. L., et al. (2005). Statistical analysis of choice experiments and surveys. Marketing Letters 16: 183-196.

McSweeney, K. and O. Coomes (2011). Climate-related disaster opens a window of opportunity for rural poor in northeastern Honduras. Proceedings of the National Academy of Sciences 108(13): 5203-5208

ME Assessment (2003). Ecosystems and human well-being: a framework for assessment. Island press, Washington DC.

Merz, B., H. Kreibich, R., Schwarze and A. H. Thieken, 2010. Assessment of economic flood damage. Natural Hazards and Earth System Sciences, 10: 1697-1724.

Messner, F., et al. (2007). Evaluating flood damages: guidance and recommendations on principles and methods. FLOODsite Project, Report T09-06-01. Available from: http:// www.floodsite.net/html/publications2.asp?documentType $=1$ [Accessed 27, July, 2015].

Middelmann-Fernandes, M. H. (2009). Flood damage estimation beyond stage - damage functions: an Australian example, Journal of Flood Risk Management 3(1): 88-96.

Mysiak, J., and A. Markandya (2009). Economic Costs of Droughts. Xerochore Project, WP2 Brief. Available from: http://www.feem.it/userfiles/attach/ 2009111010573362009.07.23_mysiak\%20jaroslav_paper.pdf [Accessed 27, July, 2015].

Nakano, K., Y. Kajitani and TAtano H. (2011). Consistent measurement of economic losses of a natural disaster considering the effect of change in price, IEEE International Conference on Systems, Man, and Cybernetics, 3489-3494.

NRC (1999). The impacts of natural disasters: a framework for loss estimation. National Academy Press, Washington DC.

NRC (2000). Risk analysis and uncertainty in flood damage reduction studies. National Academy Press, Washington DC.

OKuYAma Y., and S. SAHIN (2009). Impact estimation of disasters: a global aggregate for 1960 to 2007. World Bank Policy Research Working Papers, 4963: 1-42.

Olschewsin, R., P. Bebi, M. Teich, U. W. Hayek and A. Grêt-Regamey (2012). Avalanche protection by forests - A choice experiment in the Swiss Alps, Forest policy and Economics 17: 19-24.

Olsen, A. and K. Porter (2011). What We Know about Demand Surge: Brief Summary, Natural Hazards Review 12: 62. 
Penning-Rowsell, E., C. Johnson and S. Tunstall (2003). The benefits of flood and coastal defence: techniques and data for 2003. Middlesex University, Flood Hazard Research Centre, London.

Penning-Rowsell, E. and T. Wilson (2006). Gauging the impact of natural hazards: the pattern and cost of emergency response during flood events, Transactions of the Institute of British Geographers 31: 99-115.

Pfurtscheller, C. and R. Schwarze (2010). Kosten für den katastrophenschutzes, in A. Thieken, I. Seifert and B. Merz (eds.) Hochwassersch aden-erfassung, abschatzung und vermeidung. Oekom Verlag, München, 253-262.

Pielke, R. A. JR. (2000). Flood impacts on society, damaging floods as a framework for assessment, in: D. J. PArker (ed.) Floods. Routledge, London-New York, 133-155.

Prattenthaler, F., P. Amrusch and C. Hasburg-Lothringen (2010). Estimation of an absolute flood damage curve based on an Austrian case study under a dam breach scenario, Natural Hazards and Earth System Sciences 10: 881-894.

Rayhan, M. I. and U. Grote (2010). Crop Diversification to Mitigate Flood Vulnerability in Bangladesh: An Economic Approach, Economics Bulletin 30(1): 597-604.

Rodriguez-Oreggia, E., A. de la Fuente, R. de la Torre, H. Moreno and C. Rodriguez (2012). The Impact of Natural Disasters on Human Development and Poverty at the Municipal Level in Mexico 2002-05, Journal of Development Studies 114.

Rose, A. (2004). Economic principles, issues and research priorities of natural hazard loss estimation, in Y. Okuyama and S. Chang (eds.) Modeling of spatial economic impacts of natural hazards. Springer, Berlin, 13-36.

Rose, A. and L. Shu-Yi (2005). Modeling Regional Economic Resilience to Disasters: A Computable General Equilibrium Analysis of Water Service Disruptions, Journal of Regional Science 45(1): 75-112.

RuijgroK, E. C. M. (2006). The three economic values of cultural heritage: a case study in the Netherlands, Journal of cultural heritage 7(3): 206-213.

Samarasinghe, O. and B. Sharp (2010). Flood prone risk and amenity values: a spatial hedonic analysis, Australian Journal of Agricultural and Resource Economics 54(4): 457475.

SAHin, S. (2011). Estimation of disasters' economic impact in 1990-2007: global perspectives. World Bank, Washington DC.

SCAnlon, J. (1988). Winners and losers: some thoughts about the political economy of disaster, International Journal of Mass Emergencies and Disasters 6(1): 47-63.

SCRIECIU, S. S. (2007). The inherent dangers of using computable general equilibrium models as a single integrated modelling framework for sustainability impact assessment. A critical note on Böhringer and Löschel (2006), Ecological Economics 60(4): $678-684$.

SeIP, K. and J. Strand (1992). Willingness to pay for environmental goods in Norway: A contingent valuation study with real payment, Environmental and Resource Economics 2(1), 91-106.

Throsby, D. (2003). Determining the value of cultural goods: How much (or how little) does contingent valuation tell us?, Journal of Cultural Economics 27(3): 275-285.

Throsby, D. (2007). Regional aspects of heritage economics: analytical and policy issues, Australasian Journal of Regional Studies 13(1): 21. 
Trenberth, K.E., et al. (2007). Observations: surface and atmospheric climate change, in S. Solomon, et al. (eds.) Climate Change 2007: The Physical Science Basis, Contribution of Working Group I to the Fourth Assessment Report of the IPCC. Cambridge University Press, Cambridge, 235-336.

UNISDR (2004). Disaster risk reduction tools and methods for climate change adaptation. UNISDR, Geneva.

UNISDR (2005). Hyogo framework for action 2005-2015: building the resilience of nations and communities to disasters. UNISDR, Geneva.

UNISDR (2009). Global assessment report on disaster risk reduction - risk and poverty in a changing climate: invest today for a safer tomorrow. UNISDR, Geneva.

UN (2008). World economic and social survey 2008: overcoming economic insecurity. UN, New York.

EPA (2008). Guidelines for preparing economic analyses. US Environmental Protection Agency, Washington DC.

VAn der Veen, A. (2004). Disasters and economic damage: macro, meso and micro approaches. Disaster Prevention and Management 13(4): 274-279.

VAN Der Veen, A. and C. LogtmeiJer (2005). Economic hotspots: visualizing vulnerability to flooding, Natural Hazards 36: 65-80.

Villa, F., et al. (2014a). A methodology for adaptable and robust ecosystem services assessment. PloS one, 9(3), e91001.

Villa, F., K. J. Bagstad, B. Voigt, G. W. Johnson, I. N. Athanasiadis and S. Balbi (2014b). The misconception of ecosystem disservices: How a catchy term may yield the wrong messages for science and society, Ecosystem Services 10: 52-53

Viscusi, V. K. and E. A. Joseph (2003). The value of a statistical life: a critical review of market estimates throughout the world, Journal of Risk and Uncertainty 27(1): 5-76.

Werner, B. T. and D. E. MCNamara, (2007). Dynamics of coupled human-landscape systems, Geomorphology 91(3): 393-407.

Wind, H. G., M. Nierop, C. J. DE Blois and J. L. DE KoK (1999). Analysis of flood damages from the 1993 and 1995 Meuse floods, Water Resources Research 35(11): 34593465.

World Bank (2010). Natural hazards, unnatural disasters: the economics of effective prevention. World Bank, Washington DC.

World Bank Independent Evaluation Group (2006). Hazards of nature, risks to development. An IEG evaluation of World Bank assistance for natural disasters. World Bank, Washington DC.

Yamano, N., Y. Kajitani and Y. Shumuta (2007). Modeling the regional economic loss of natural disasters: the search for economic hotspots. Economic Systems Research, 19(2), 163-181.

Zhai, G., T. Fukuzono and S. Ikeda (2007). Multi-attribute evaluation of flood management in Japan: a choice experiment approach, Water and Environment Journal 21(4): 265-274. 



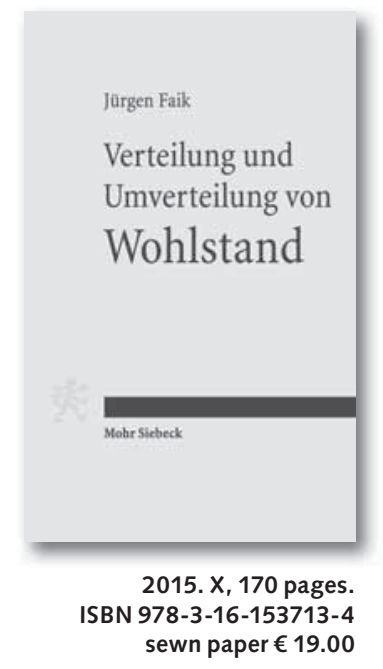

Wie hoch ist die deutsche Wohlstandsungleichheit, und wie lässt sie sich vermindern? Jürgen Faik schildert die empirischen Entwicklungen hinsichtlich der zunehmenden Wohlstandspolarisierung in Deutschland ausführlich und stellt sie in einen wirtschaftlichen, demografischen und gesellschaftlichen Erklärungskontext. Außerdem zeigt er Lösungsansätze wie eine stärkere Besteuerung von Kapital - auf.
Jürgen Faik

Verteilung und

Umverteilung von

Wohlstand

Bestandsaufnahme und Folgen

der sozialen Polarisierung in

Deutschland

Die Debatten um Einkommens- und Vermögensungleichheit sind zuletzt durch die Wirtschafts- und Finanzkrise seit 2007 belebt worden. Vor diesem Hintergrund zeigt Jürgen Faik Polarisierungstendenzen bezüglich der entsprechenden Ressourcenverteilungen in Deutschland auf und diskutiert diese kritisch. Seine Überlegungen schließen Verteilungswahrnehmungen seitens der bundesdeutschen Bevölkerung ein. Er macht deutlich, dass die beobachtete Wohlstandspolarisierung bereits jetzt $\mathrm{zu}$ einer Gefahrenquelle für die politische Demokratie in Deutschland geworden ist. Daher setzt sich der Autor mit Lösungsansätzen auseinander, die aus seiner Sicht $\mathrm{zu}$ einer Verminderung der bestehenden Ungleichheit beitragen. Zu nennen sind zielgruppenspezifische Redistributionsmaßnahmen, die über eine Ausweitung der Steuerprogression (vor allem über eine stärkere Besteuerung des Produktionsfaktors Kapital) finanziert werden sollten.

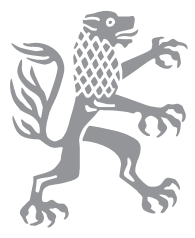

\section{Mohr Siebeck}

Tübingen

info@mohr.de

www.mohr.de

Custom made information: www.mohr.de 


\section{Zeitschrift für Wirtschaftspolitik}

Herausgegeben vom Institut für Wirtschaftspolitik an der Universität zu Köln: Juergen B. Donges, Steffen J. Roth, Achim Wambach, Christian Watrin

Die Zeitschrift ist offen für wirtschaftswissenschaftliche Beiträge aller Richtungen und wendet sich an alle an Wirtschaftspolitik interessierte Forscher und Praktiker. Im Mittelpunkt jeder Ausgabe steht das wirtschaftspolitische Forum. Es behandelt solche Themen, die in der Öffentlichkeit zum Teil sehr kontrovers diskutiert werden.

Abonnementspreise 2015 (3 Hefte pro Jahrgang)

EUR 72,-; Institutionen EUR 118,-; Studierende 36,- (jeweils zuzügl. Versandkosten (3,- Inland/6,- Ausland). Online-Zugang im institutionellen Preis enthalten, für alle anderen zuzüglich 12,- pro Jahr.

Übersicht der zuletzt erschienenen Hefte:

Heft 1 / 2015 (64. Jahrgang)

Interaktionseffekte zwischen Mindestlöhnen und Lohnsubventionen.

Eine Analyse zur Beschäftigung in den USA und in Deutschland

Norbert Berthold und Mustafa Coban

\section{Wirtschaftspolitisches Forum}

Gesetzliche Einhegung der Tarif-

pluralität? - Zur Debatte um eine

staatlich verordnete Tarifeinheit

Claus Schnabel, Ronald Bachmann

und Christoph M. Schmidt, Martin

Henssler

Zur Beschäftigungsentwicklung in

Deutschland

Hubert Schnabel

Spartengewerkschaften, Statuskon-

flikte und Gemeinwohl: Gesetzlicher

Ordnungsrahmen statt Laissez-faire

Hagen Lesch

\section{Heft 2 / 2015 (64. Jahrgang)}

Werte und Institutionen im Wettbewerb. Wirtschaftspolitik, Moral und Verantwortung unter den Bedingun- gen des gesellschaftlichen Wandels Christian Hecker

Reform des EU-Emissionshandels:

Eine Alternative zu Mindestpreisen für Zertifikate und der Marktstabilitätsreserve

Mark A. Andor, Manuel Frondel und Stephan Sommer

\section{Wirtschaftspolitisches Forum \\ Auswirkungen der anhaltenden \\ Niedrigzinsen auf das Versicherungs- wesen \\ Helmut Gründl, Rolf Ketzler und Peter Schwark, Heinrich R. Schradin}

Schwache Unternehmensinvestitionen in Deutschland? Diagnose und Therapie

Hubertus Bardt, Michael Grömling und Michael Hüther

Der OECD-Aktionsplan gegen die Steuervermeidung multinationaler Unternehmen - eine ordnungsökonomische Analyse der Maßnahmen und Reformoptionen Marco C. Melle

$$
\frac{\mathrm{LUCIUS}}{\mathrm{LUCIUS}}
$$

